\title{
CLINICAL SIGNIFICANCE OF THE MUSCULUS GLUTEUS MINIMUS IN TOTAL HIP ARTHROPLASTY
}

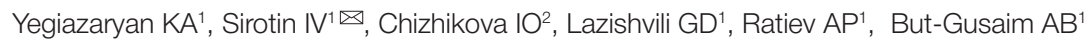

1 Pirogov Russian National Research Medical University, Moscow, Russia

2 Bureau of Forensic Medical Expertise, Moscow Department of Health, Moscow, Russia

Dislocation of the acetabular component is one of the most frequent complications of total hip arthroplasty. It is commonly attributed to implant malpositioning. However, not all dislocations can be explained by this hypothesis. The aim of our study was to elucidate the role of intraoperative injury to hip abductors ( $m$. gluteus minimus in the first place, since it is reportedly an important hip stabilizer) in the development of postoperative hip dislocation. The experiment was conducted in 4 male and 3 female cadavers. A total of 12 THA were performed. The Hardinge and Watson-Jones approaches were used in equal proportion. On plain radiography, acetabular inclination was $40-47^{\circ}$, anteversion was $10-22^{\circ}$; technically and biomechanically, these values were within the normal range and did not depend on the type of surgical approach (for inclination, $p=0.94$; for anteversion, $p=0.63$ ), ruling out implant malpositioning as a risk factor for hip dislocation. Nevertheless, implant stability was significantly disrupted following transection of the anterior or posterior fascicle of $m$. g/uteus minimus, leading to the dislocation of the acetabular component in standard rotation and flexion tests. Thus, our study shows the significant role of $m$. gluteus minimus in stabilizing the hip joint. Preservation or adequate repair of this muscle during surgery will reduce the risk or dislocation and help to restore the anatomy and biomechanics of the operated joint.

Keywords: hip dislocation after arthroplasty, m.gluteus minimus, hip abductor, hip arthroplasty, hip approach

Author contribution: Yegiazaryan KA supervised the study, analyzed the literature and contributed to writing the manuscript; Sirotin IV, Chizhikova IO analyzed the literature, conducted the experimental part of the study and contributed to writing the manuscript; Lazishvili GD, Ratiev AP, But-Gusaim AB analyzed the literature and contributed to writing the manuscript.

Compliance with ethical standards: the study followed the principles of the Declaration of Helsinki by the World Medical Association.

$\triangle$ Correspondence should be addressed: Ivan V. Sirotin

Ostrovityanova, 1, 117997, Moscow; ivsir@mail.ru

Received: 04.09.2020 Accepted: 18.09.2020 Published online: 04.10.2020

DOI: $10.24075 /$ brsmu.2020.058

\section{КЛИНИЧЕСКОЕ ЗНАЧЕНИЕ МАЛОЙ ЯГОДИЧНОЙ МЫШЦЫ ПРИ ЭНДОПРОТЕЗИРОВАНИИ ТАЗОБЕДРЕННОГО СУСТАВА}

\author{
К. А. Егиазарян ${ }^{1}$, И. В. Сиротин ${ }^{1 凶}$, И. О. Чижикова ${ }^{2}$, Г. Д. Лазишвили ${ }^{1}$, А. П. Ратьев ${ }^{1}$, А. Б. Бут-Гусаим \\ ${ }^{1}$ Российский национальный исследовательский медицинский университет имени Н. И. Пирогова, Москва, Россия \\ 2 Бюро судебно-медицинской экспертизы Департамента здравоохранения города Москвы, Москва, Россия
}

\begin{abstract}
Возникновение вывихов бедренного компонента эндопротеза - одно из частых осложнений эндопротезирования тазобедренного сустава. Наиболее популярным объяснением возникновения данного осложнения является мальпозиция компонентов эндопротеза. Однако не все вывихи удается объяснить исходя из данной гипотезы. Целью работы было уточнить значение в генезе данного осложнения повреждения мышц абдукторов бедра и в первую очередь $m$. gluteus minimus, описываемой в ряде источников как важный стабилизатор тазобедренного сустава. Для изучения данного тезиса был поставлен эксперимент с использованием четырех мужских и трех женских биоманекенов. Было произведено 12 установок эндопротеза тазобедренного сустава. В равных долях применяли доступы по Hardinge и Watson-Jones. По данным рентгенконтроля, наклон вертлужного компонента

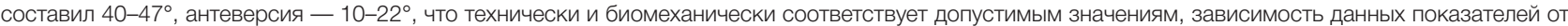
типа доступа статистически не значима (для наклона вертлужного компонента $p=0,94$; для антеверсии вертлужного компонента $p=0,63$ ), что исключало мальпозицию компонентов как фактор риска вывиха. Тем не менее при пересечении переднего или заднего пучка m. gluteus minimus стабильность эндопротеза существенно нарушалась, что приводило к вывиху бедренного компонента при выполнении стандартных тестов ротации и сгибания. Таким образом, показана значимость $m$. gluteus minimus в стабилизации тазобедренного сустава. Сохранение или тщательное восстановление ее структуры в ходе выполнения операции позволит не только провести просилактику возникновения вывиха, но и восстановить более правильную анатомию и биомеханику оперированного сустава.
\end{abstract}

Ключевые слова: вывих эндопротеза тазобедренного сустава, малая ягодичная мышца, абдукторы бедра, артропластика тазобедренного сустава, доступ к тазобедренному суставу

Вклад авторов: К. А. Егиазарян - общее руководство работой, анализ литературы, написание статьи; И. В. Сиротин, И. О. Чижикова - анализ литературы, проведение экспериментального исследования, написание статьи; Г. Д. Лазишвили, А. П. Ратьев, А. Б. Бут-Гусаим - анализ литературы, написание статьи.

Соблюдение этических стандартов: исследование проведено с соблюдением этических принципов медицинских исследований Хельсинской декларации Всемирной медицинской ассоциации.

$\searrow$ Для корреспонденции: Иван Владимирович Сиротин ул. Островитянова, д. 1, г. Москва, 117997; ivsir@mail.ru

Статья получена: 04.09.2020 Статья принята к печати: 18.09.2020 Опубликована онлайн: 04.10.2020

DOI: 10.24075/vrgmu.2020.058

Total hip arthroplasty (THA) is a surgical treatment of choice for a damaged hip joint. According to most estimates, its success rate ranges from 92 to $95 \%$. However, low as it is, the rate of THA complications remains stable over the years, showing no significant improvement [1].

Postoperative dislocation of the acetabular hip component is a serious complication of THA and is largely associated with the use of a posterior approach to the hip. However, dislocation is also reported for patients who had the lateral or anterolateral Hardinge or Watson-Jones approach traditionally viewed as safer. In some cases, the underlying cause of dislocation is implant malposition and a movement beyond the recommended range that forces the joint out of the socket [2-4]. 
Deficiency of hip abductors, including $\mathrm{m}$. gluteus medius and $m$. gluteus minimus, is another factor predisposing to dislocation after THA. Abductor deficiency can be very pronounced following a fracture of trochanter major, the main attachment site for these muscles. In some cases, the true cause of postoperative dislocation remains unknown. Some authors point out that apart from abduction itself, hip abductors (m. gluteus minimus in particular) are responsible for stabilizing or "centering" the femoral head in the socket and rotating the hip externally and internally [5, 6]. M. gluteus medius and $m$. gluteus minimus are broad, thick, short muscles with a broad tendon that originate proximally on the outer surface of the ilium and insert distally into trochanter major et fossa piriformis. Some studies of human anatomy and abductor tendinopathy refer to this group of muscles as the hip rotator cuff, similar to the rotator cuff of the shoulder joint.

Magnetic resonance imaging made it possible to more precisely identify the sites of $m$. gluteus medius and $m$. gluteus minimus insertion on the greater trochanter and to describe their functions. M. gluteus medius attaches to the posterosuperior and lateral facets of the greater trochanter; 3 fascicles of this muscle stabilize the pelvis during gait initiation and are also involved in pelvic rotation. The fibers of $m$. gluteus minimus course toward the internal surface of the anterosuperior facet of the greater trochanter; its fibers are oriented horizontally and play the role of key stabilizers in the mid and terminal gait phases [7].

In-depth studies of muscle anatomy provide an insight into how functions are distributed among separate bundles of fibers constituting these muscles. The anterior and posterior fascicles can be clearly distinguished in the structure of m. gluteus medius; they are responsible for external and internal hip rotation, respectively [8]. Although there is only a limited number of studies addressing the anatomy of $m$. gluteus minimus, some of them report the functional division of its fascicles, similarly to $m$. gluteus medius [8].

Previously, it was hypothesized that $m$. gluteus minimus might promote stabilization of both the native hip joint and the implant [5]. Due to intimate bonding with the fibers of the joint capsule, this muscle might not only "drive" hip movements but also stabilize the joint, similarly to pes anserinus in the knee joint. This hypothesis, however, did not take off.

The aim of this work was to test the hypothesis that $m$. gluteus minimus can play a significant role in hip dislocation following THA.

\section{METHODS}

The experiment was conducted in cadavers after the resolution of rigor mortis; the cadavers did not have visible signs of damage to the gluteal and hip regions. For hip replacement, we used instrumentation by DePuy, USA, and a CORAIL-PINNACLE hip construct by the same manufacturer. At our disposal, we had $28-\mathrm{mm}$ trial femoral heads with +1.5 to $+12 \mathrm{~mm}$ offset. The Hardinge and Watson-Jones approaches to the hip were used in all cases. All surgeries were performed by an experienced surgeon who had done over 500 hip replacements over the past 3 years using these traditional approaches.

For the experiment, 4 male and 3 female cadavers (78-86 years) were selected, comparable in terms of their anthropometric characteristics; THA was performed on 3 male (mean age 82.33 years) and 3 female (mean age 84.33 years) cadavers with the normosthenic body type and no visible damage to the pelvis and lower limbs (see Table).

The remaining cadaver was exploited for primary visualization of $m$. gluteus minimus; THA was not performed on this cadaver.

In total, 12 hip replacements were performed, one on each body side. The Hardinge and Watson-Jones approaches were used in equal proportion. Implant positioning was assessed on plain radiographs using the Lewinnek method [9] (Fig. 1).

Differences in inclination and anteversion of the acetabular hip component between the applied surgical approaches were compared using the Mann-Whitney $U$ test. Statistical analysis was carried out using open Python libraries.

\section{RESULTS}

Firstly, we indirectly assessed the role of $m$. gluteus minimus in hip rotation. For better muscle visualization, the portion of $m$. gluteus medius overlying $m$. gluteus minimus was removed. The anterior and posterior sections of the muscle belly were clearly distinguishable, meaning that there were 2 fiber bundles sharing a broad tendonous part (Fig. 2).

We found that fibers and tendons constituting the anterior fascicle of $m$. gluteus minimus stretched during external hip rotation, whereas the posterior fascicle stretched on hip flexion and internal rotation, limiting the possible range of motion. This observation inspired a hypothesis that $m$. gluteus minimus might have a significant role in the stabilization of a native hip joint.

Table. Characteristics of surgeries, including age and sex of the cadavers, the operated body side, surgical approaches, acetabular inclination and anteversion

\begin{tabular}{|c|c|c|c|c|c|}
\hline Sex & Age & Side & Access & Acetabular inclination & Acetabular anteversion \\
\hline $\mathrm{f}$ & 82 & left & Hardinge & 40 & 12 \\
\hline $\mathrm{f}$ & 82 & right & Watson-Jones & 42 & 20 \\
\hline $\mathrm{f}$ & 84 & left & Watson-Jones & 45 & 22 \\
\hline $\mathrm{f}$ & 84 & right & Hardinge & 46 & 15 \\
\hline $\mathrm{f}$ & 87 & left & Hardinge & 47 & 17 \\
\hline $\mathrm{f}$ & 87 & right & Watson-Jones & 45 & 20 \\
\hline $\mathrm{m}$ & 78 & left & Watson-Jones & 42 & 21 \\
\hline $\mathrm{m}$ & 78 & right & Hardinge & 43 & 20 \\
\hline $\mathrm{m}$ & 83 & left & Hardinge & 41 & 12 \\
\hline $\mathrm{m}$ & 83 & right & Watson-Jones & 45 & 10 \\
\hline $\mathrm{m}$ & 86 & left & Watson-Jones & 46 & \\
\hline $\mathrm{m}$ & 86 & right & Hardinge & 45 & \\
\hline
\end{tabular}

Note: $m$ - male; $f$ - female. 
In the second step, we performed THA using the traditional Hardinge and Watson-Jones approaches. After the implant was installed, a section of $m$. gluteus medius just above $m$. gluteus minimus was removed for better visualization. Both surgical approaches resulted in the injury to the anterior portion of $m$. gluteus minimus; the damage was slightly more pronounced for the Hardinge approach. The joint capsule was not dissected but closed with sutures. Measured on plain radiographs, acetabular inclination was $40-47^{\circ}$, anteversion was $10-22^{\circ}$; technically and biomechanically, these values were within the normal range. Then, the hip was rotated inward and outward with the maximum amplitude possible for the cadaver under examination and flexed to $90^{\circ}$. These movements did not provoke dislocation of the acetabular component. However, with the Hardinge approach, a femoral head with a bigger offset was used to ensure joint stability. Traction of the acetabular component with a surgical instrument along the axis of the prosthetic neck (after the joint capsule was dissected) did not cause the escape of the prosthetic femoral head from the cup.

After the implant was installed and the joint capsule was repaired, the anterior fascicle of $m$. gluteus minimus was transversely transected and the posterior fascicle was left intact. Then, the hip was rotated outward with the maximum possible amplitude. This resulted in the dislocation of the initially stable implant but did not damage the joint capsule. Attempts to compensate for the instability of the implant by using femoral heads with more offset were unsuccessful. Traction of the acetabular component with a surgical instrument along the axis of the prosthetic neck (after the joint capsule was dissected) caused the escape of the prosthetic femoral head from the cup during hip flexion.

In the fourth step, we transversely transected the posterior fascicle of $m$. gluteus minimus, leaving its anterior fascicle intact. Then, the hip was rotated inward and flexed or just flexed without rotation, using the maximum possible amplitude. The combination of hip flexion and inward rotation resulted in the dislocation of the initially stable implant but did not damage the joint capsule. Attempts to compensate for the instability of the implant by using femoral heads with more offset were unsuccessful. Traction of the acetabular component with a surgical instrument along the axis of the prosthetic neck (with the opened joint capsule) caused the escape of the prosthetic femoral head during hip flexion.

On plain radiography, inclination of the acetabular component was $40-47^{\circ}$, anteversion was $10-22^{\circ}$; technically and biomechanically, these values were within the normal range (see Table). No statistical differences were detected in mean acetabular inclination and anteversion values for the WatsonJones and Hardinge approaches (for inclination, $p=0.94$; for anteversion, $p=0.63$ ), suggesting that implant malposition was not the case in our study and could not be a risk factor for postoperative hip dislocation.

\section{DISCUSSION}

The modern literature looks at hip abductors from 2 different perspectives. Firstly, degenerative or traumatic injury of hip abductors causes pronounced pain and gait disturbance [10]. Secondly, abductor rupture (due to trochanter major fracture) or weakness (caused by an injury to nervus gluteus superior) precipitates the instability of the artificial joint [11].

It was shown that the physiological cross-sectional area of $m$. gluteus minimus is smaller than that of $m$. gluteus medius, suggesting that the force of $\mathrm{m}$. gluteus minimus contraction is proportionally weaker [12]. Perhaps, the architecture of separate

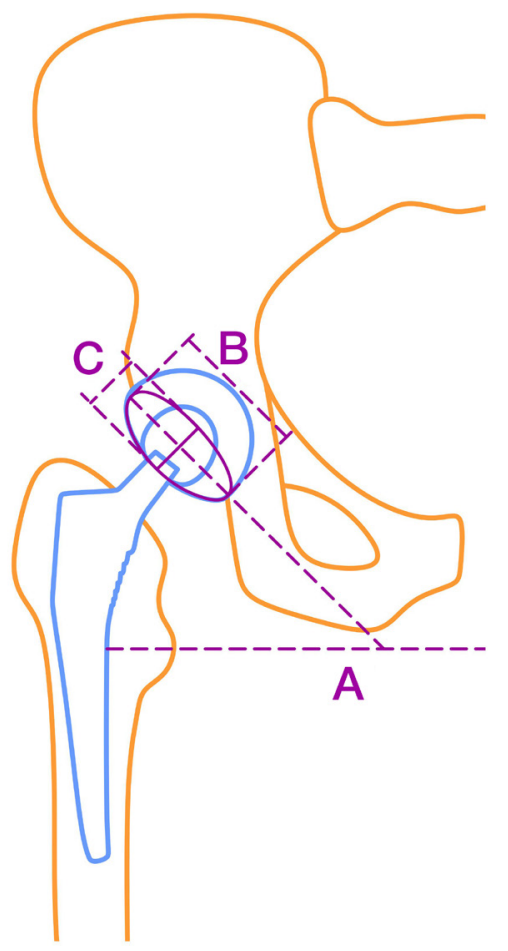

Fig. 1. Measuring acetabular inclination and anteversion (cup inclination is calculated as the angle between the horizontal line $\mathbf{A}$ and the continuation of the long axis $\mathbf{B}$ of the ellipsis; anteversion is calculated as arcsin (short axis $\mathbf{C}$ / long axis $\mathbf{B}$ )

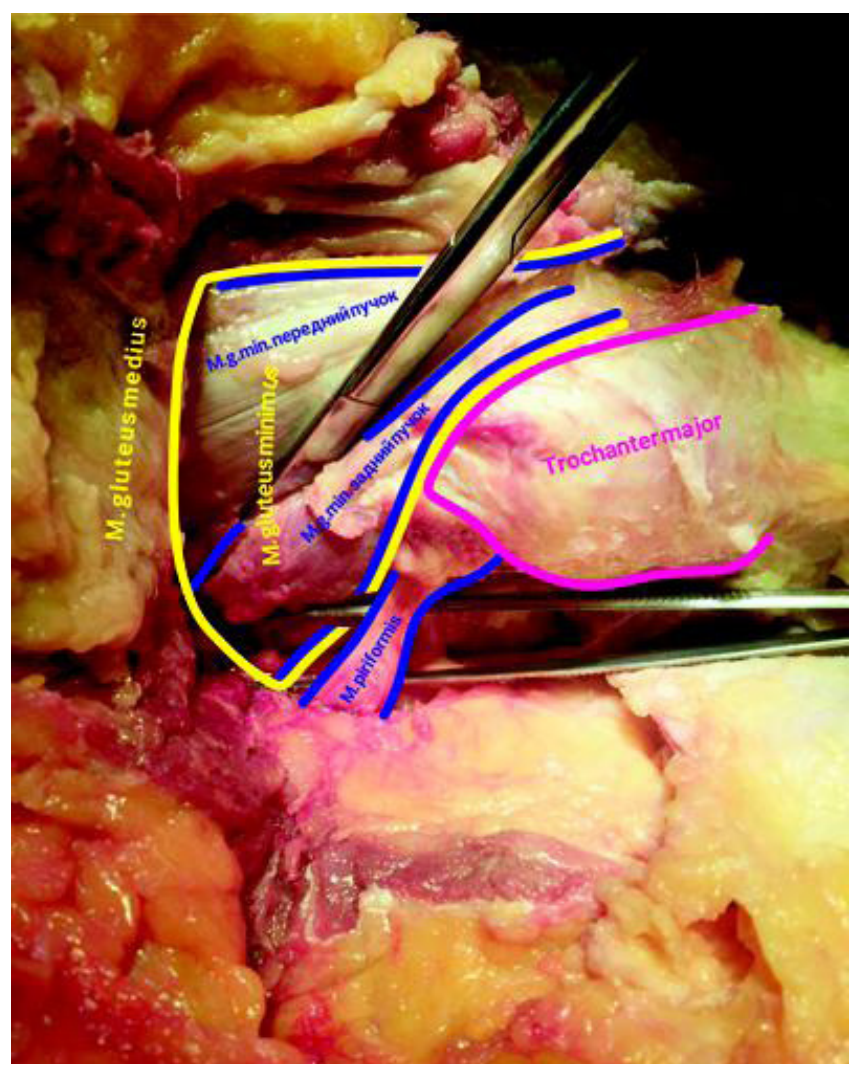

Fig. 2. The region of the greater trochanter featuring the site of $m$. gluteus minimus attachment and parts of external hip rotators (see the article)

bundles of $m$. gluteus minimus determines the stabilizing function of this muscle. In a series of dissections, some of m. gluteus minimus fascicles were found to be attached to the joint capsule, but the functional role of such bonding, its prevalence and force are still a matter of debate $[6,13]$. 
Ultrasonography and functional tests conducted in vivo revealed that the thickness of hip abductors does not correlate with their strength or function; the authors of the study hypothesized that this was due to the inability of applying the tests to separate muscle bundles in vivo [14].

There is a paucity of studies exploring the functions of hip abductors in general and $m$. gluteus minimus in particular. This can be partially explained by the fact that hip abductor pathology unrelated to conditions requiring hip replacement is relatively rare and usually responds well to traditional therapy; in such cases, no detailed investigation of abductor anatomy is needed.

Being an effective orthopedic surgery, THA is not free of complications, although their rate is low. Better understanding of causes underlying THA complications will help to reduce their risks, contribute to the knowledge of biomechanics of both native and artificial hip joints, improve the quality of treatment, and develop effective regimens for such complications.

Our study looked at the possibility of injuring $\mathrm{m}$. gluteus minimus during hip replacement with lateral approaches to the hip. Our findings and results of some other studies [15] also suggest a significant role of intraoperative injury to the posterior fascicle of $\mathrm{m}$. gluteus minimus in postoperative complications following the use of posterior approaches to the hip. Although repair of the tendinous section of $m$. piriformis is crucial for maintaining stability of the hip joint in hip replacement with posterior approaches, injury to this region remains a probable cause of posterior acetabular dislocations in patients with repaired $m$. piriformis.

\section{CONCLUSION}

We have demonstrated a significant role of $\mathrm{m}$. gluteus minimus in stabilizing the hip joint, especially in artificial hips following THA. Preservation or adequate repair of $m$. gluteus minimus when performing surgical access or closing soft tissue is a good prophylaxis for postoperative dislocation and helps to restore the anatomy and biomechanics of the hip joint. Further research is needed to better understand the functions of $m$. gluteus minimus and other muscles and ligaments surrounding the hip joint in the context of their contribution to implant stability and the range of motion, similarly to the knee joint.

\section{References}

1. Learmonth ID, Young C, Rorabeck C. The operation of the century: total hip replacement. Lancet. 2007; 370: 1508-19.

2. De Martino I, Triantafyllopoulos GK, Sculco PK, Sculco TP. Dual mobility cups in total hip arthroplasty. World J Orthop. 2014; 5: 180-7.

3. De Martino I, D'Apolito R, Soranoglou VG, Poultsides LA, Sculco PK, Sculco TP Dislocation following total hip arthroplasty using dual mobility acetabular components: a systematic review. Bone Joint J. 2017 Jan; 99-B (ASuppl1): 18-24.

4. Tsikandylakis G, Kärrholm JN, Hallan G, Furnes O, Eskelinen A, Mäkelä K, Pedersen AB, Overgaard $S$, Mohaddes $M$. Is there a reduction in risk of revision when $36-\mathrm{mm}$ heads instead of $32 \mathrm{~mm}$ are used in total hip arthroplasty for patients with proximal femur fractures? Acta Orthop. 2020 Apr 14: 1-7.

5. Beck M, Sledge JB, Gautier E, Dora CF, Ganz R.J The anatomy and function of the gluteus minimus muscle. Bone Joint Surg Br. 2000 Apr; 82 (3): 358-63.

6. Flack NA, Nicholson HD, Woodley SJ. The anatomy of the hip abductor muscles. Clin Anat. 2014; 27 (2): 241-53.

7. Pfirrmann CW, Chung CB, Theumann NH, Trudell DJ, Resnick D. Greater Trochanter of the Hip: Attachement of the Abductor Mechanism and a Complex of three bursae - MR Imaging and MR Bursography in Cadavers and MR Imaging in Asymptomatic Volunteers. Radiology. 2001; 221 (2): 469-77.

8. Conneely M, O'Sullivan K, Edmondston S. Dissection of gluteus maximus and medius with respect to their suggested roles in pelvic and hip stability: Implications for rehabilitation? Phys Therapy Sport Conf Proc. 2006; 7: 176-8.

9. Park YS, Shin WC, Lee SM, et al. The Best Method for Evaluating Anteversion of the Acetabular Component After Total Hip Arthroplasty on Plain Radiographs. J Orthop Surg Res. 2018 Apr 2; 13 (1): 66.

10. Gulledge CM, Makhni EC. Open Gluteus Medius and Minimus Repair With Double-Row Technique and Bioinductive Implant Augmentation. Arthrosc Tech. 2019 May 17; 8 (6): e585-e589.

11. Kung PL, Ries MD. Effect of Femoral Head Size and Abductors on Dislocation after revision THA. Clin Orthop Relat Res. 2007; 465: 170-4.

12. Parvaresh KC, Chang C, Patel A, Lieber RL, Ball ST, Ward SR. Architecture of the Short External Rotator Muscles of the Hip. BMC Musculoskelet Disord. 2019; 20 (1): 611.

13. Walters J, Solomons M, Davies J. Gluteus minimus: observations on its insertion. J Anat. 2001; 198 (Pt 2): 239-42.

14. Whiler L, Fong M, Kim S, et al. Gluteus Medius and Minimus Muscle Structure, Strength, and Function in Healthy Adults: Brief Report. Physiother Can. 2017; 69 (3): 212-16.

15. Whiteside LA, Roy ME. Incidence and Treatment of Abductor Deficiency During Total Hip Arthroplasty Using the Posterior Approach: Repair With Direct Suture Technique and Gluteus Maximus Flap Transfer. Bone Joint J. 2019 Jun; 101-B (6_ Supple_B): 116-22.

\section{Литература}

1. Learmonth ID, Young C, Rorabeck C. The operation of the century: total hip replacement. Lancet. 2007; 370: 1508-19.

2. De Martino I, Triantafyllopoulos GK, Sculco PK, Sculco TP. Dual mobility cups in total hip arthroplasty. World J Orthop. 2014; 5: 180-7.

3. De Martino I, D'Apolito R, Soranoglou VG, Poultsides LA, Sculco PK, Sculco TP Dislocation following total hip arthroplasty using dual mobility acetabular components: a systematic review. Bone Joint J. 2017 Jan; 99-B (ASuppl1): 18-24.

4. Tsikandylakis G, Kärrholm JN, Hallan G, Furnes O, Eskelinen A, Mäkelä K, Pedersen AB, Overgaard S, Mohaddes M. Is there a reduction in risk of revision when $36-\mathrm{mm}$ heads instead of $32 \mathrm{~mm}$ are used in total hip arthroplasty for patients with proximal femur fractures? Acta Orthop. 2020 Apr 14: 1-7.

5. Beck M, Sledge JB, Gautier E, Dora CF, Ganz R.J The anatomy

and function of the gluteus minimus muscle. Bone Joint Surg Br. 2000 Apr; 82 (3): 358-63.

6. Flack NA, Nicholson HD, Woodley SJ. The anatomy of the hip abductor muscles. Clin Anat. 2014; 27 (2): 241-53.

7. Pfirmann CW, Chung CB, Theumann NH, Trudell DJ, Resnick D. Greater Trochanter of the Hip: Attachement of the Abductor Mechanism and a Complex of three bursae - MR Imaging and MR Bursography in Cadavers and MR Imaging in Asymptomatic Volunteers. Radiology. 2001; 221 (2): 469-77.

8. Conneely M, O'Sullivan K, Edmondston S. Dissection of gluteus maximus and medius with respect to their suggested roles in pelvic and hip stability: Implications for rehabilitation? Phys Therapy Sport Conf Proc. 2006; 7: 176-8.

9. Park YS, Shin WC, Lee SM, et al. The Best Method for Evaluating 
Anteversion of the Acetabular Component After Total Hip Arthroplasty on Plain Radiographs. J Orthop Surg Res. 2018 Apr 2; 13 (1): 66.

10. Gulledge CM, Makhni EC. Open Gluteus Medius and Minimus Repair With Double-Row Technique and Bioinductive Implant Augmentation. Arthrosc Tech. 2019 May 17; 8 (6): e585-e589.

11. Kung PL, Ries MD. Effect of Femoral Head Size and Abductors on Dislocation after revision THA. Clin Orthop Relat Res. 2007; 465: 170-4.

12. Parvaresh KC, Chang C, Patel A, Lieber RL, Ball ST, Ward SR. Architecture of the Short External Rotator Muscles of the Hip.
BMC Musculoskelet Disord. 2019; 20 (1): 611

13. Walters J, Solomons M, Davies J. Gluteus minimus: observations on its insertion. J Anat. 2001; 198 (Pt 2): 239-42.

14. Whiler L, Fong M, Kim S, et al. Gluteus Medius and Minimus Muscle Structure, Strength, and Function in Healthy Adults: Brief Report. Physiother Can. 2017; 69 (3): 212-16.

15. Whiteside LA, Roy ME. Incidence and Treatment of Abductor Deficiency During Total Hip Arthroplasty Using the Posterior Approach: Repair With Direct Suture Technique and Gluteus Maximus Flap Transfer. Bone Joint J. 2019 Jun; 101-B (6_ Supple_B): 116-22. 